The impacts of country of origin, price, and brand on consumer behavior toward cosmetics products: A review of Vietnam

Luong, Duy Binh

Department of Business Administration, Saigon University, Vietnam (duybinh0106@yahoo.com)

Vo, Thi Huong Giang $\<$

Department of Business Administration and Tourism, Ho Chi Minh City University of Food Industry, Vietnam (vthg0510@gmail.com)

Le, Khoa Nguyen

Center for Development Study, HCM Open University, Vietnam (Nguyen.lk@ou.edu.vn)

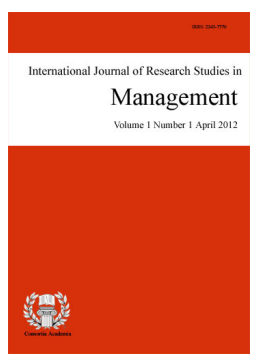

ISSN: $2243-7770$ Online ISSN: 2243-7789

OPEN ACCESS

\title{
Abstract
}

Along with the increasing needs of beauty and personal care in modern life, cosmetics become more and more necessary for not only women but also men all over the world. Based on the papers with relevant theories and literature included, this study gave an overview of the impact of extrinsic cues related to cosmetic products such as brand, price and country-of-origin (COO) on female consumers, and also the cosmetic industry in Vietnam. The results may help generate a possible model or basis for the future research on consumer behavior.

Keywords: country of origin; price; brand; cosmetics; Vietnam 


\section{The impacts of country of origin, price, and brand on consumer behavior toward cosmetics products: A review of Vietnam}

\section{Introduction}

Today cosmetics play a significant role for both men and women everywhere because they are used to enhance their appearance. Cosmetics have been around for many centuries. The Food and Drug Administration (FDA) in USA, which regulates to cosmetics, defines cosmetic as "intended to be applied to the human body for cleansing, beautifying, promoting attractiveness, or altering the appearance without affecting the body's structure or functions". The first known people who used cosmetics to enhance their beauty were the Egyptians and Greeks (Schneider et al., 2001).The appearance of advertising industry and the innovation of technology in the $19^{\text {th }}$ century made cosmetics become more popular to users than before. The development of cosmetics kept increasing in the $20^{\text {th }}$ century (Millikan, 2001) and was used mostly by girls at young age (Anderson, 2014). In the past, only people, especially women, in the high class were able to afford the cosmetics products because cosmetics belong to luxury goods; however in modern society, they are considered as more and more necessity in daily life. In context of the development of socio-economics today, the increasing needs of beauty and personal care lead to the beauty market expansion as well as the cosmetic industry development. Thus the cosmetics companies focus on offering effective, attractive and safe products to consumers.

In the last decade, global cosmetic industry has grown steadily by $3.8 \%$ on average per year, ranging from around $2.9 \%$ to $5 \%$ (Figure 1). The downturn of worldwide economy in 2009 led to the drop of the industry in growth rate but it recovered speedily in 2010 by $4.2 \%$. In a report, the global beauty care industry is forecasted to increasingly reach $\$ 265$ billion by 2017 (Yeomans, 2012). This suggested a steady and continuous growth in cosmetic industry at the present and in the future. Cosmetics products are commonly categorized into six groups: skincare, haircare, make-up, fragrances, hygiene products and oral cosmetics. Besides, cosmetics are also subdivided into premium and mass product segments (Lopaciuk \& Loboda, 2013).

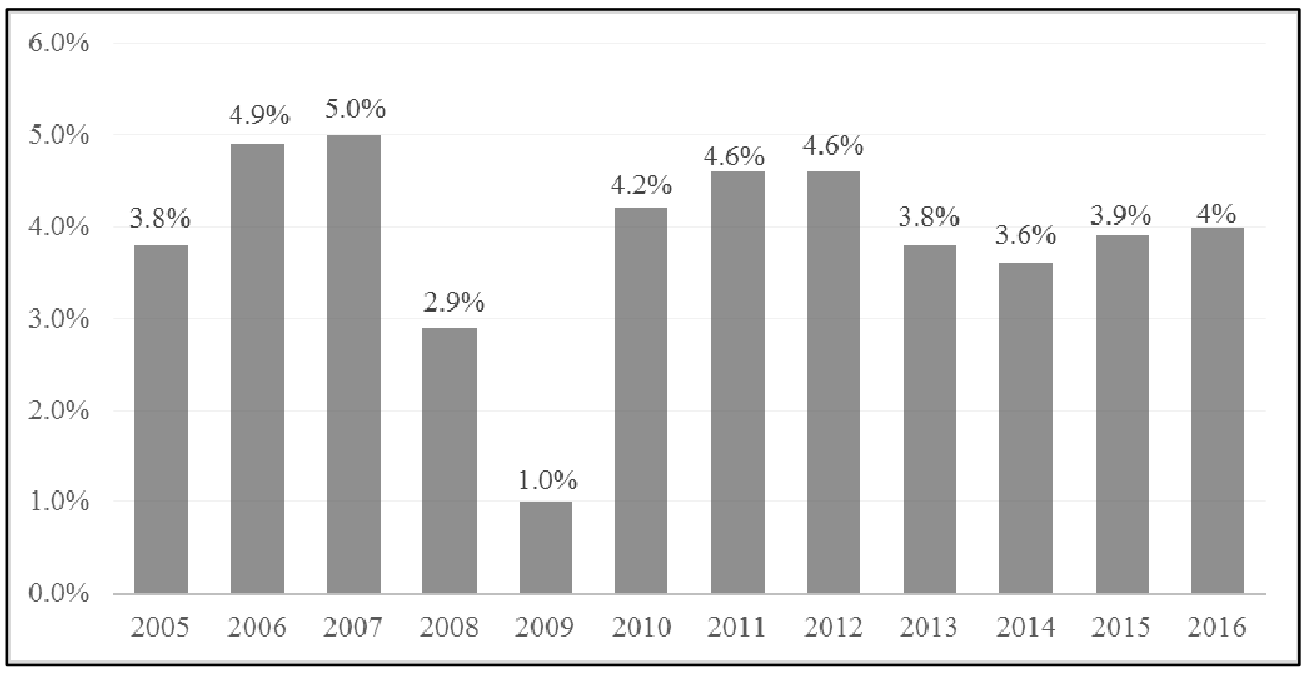

Figure 1. Annual growth of the global cosmetics markets from 2005 to 2016 (Source: The Statistics Portal, 2016)

In 2016, with the market value of $36.4 \%$, larger than in 2015 by $36.1 \%$ and in 2014 by $35.3 \%$, skincare was the significant and potential segment of global cosmetic market (Figure 2). According to Euromonitor International, from 2016 to 2021 the global beauty care industry is forecasted to have a premium growth with a CAGR of 3.6\%. Therein global skincare market is estimated to be 121 billion US Dollar by 2021. Therefore skincare is also the largest revenue segment and also estimated with huge and potential growth. In skincare 
The impacts of country of origin, price, and brand on consumer behavior toward cosmetics products

market, facial care takes two third of the total sales, followed by hand and body care and sun care (Lopaciuk \& Loboda, 2013), and was accounted for $64.1 \%$ in 2011.

Figure 2. Breakdown of the global cosmetics market in 2016 by product category (Source:

The Statistics Portal, 2016)

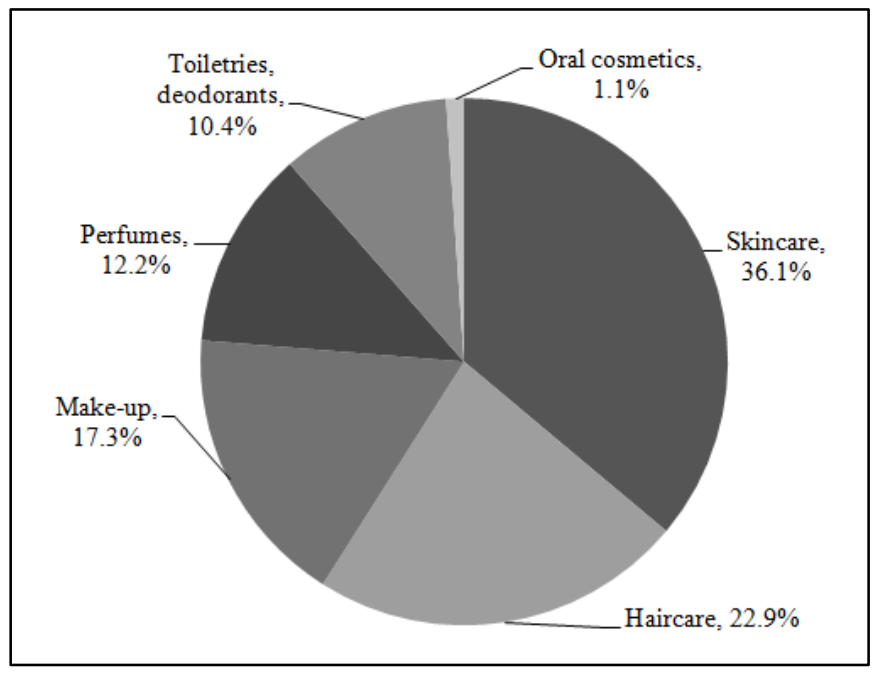

The change of various distribution channels structure in recent years has also affected the growth of global cosmetic industry. As the technologies develop, cosmetics companies take advantage to have more opportunities to advertise their products and due to the dynamics of internet, the online sales channels are growing rapidly through social network. Besides, with significant transformation of the economic situation in emerging markets, which influences dramatically the disposable incomes and the demands of consumers, cosmetics industry today has been focusing on expanding in developing countries. According to the distribution of global cosmetics products, Asia Pacific contributed the major share of about 36\% in 2015 as shown in figure 3 to the global cosmetics market. It represents the highest growth and largest segment in the cosmetic market in general and skincare market in particular. And Asia was also predicted by Euromonitor International (2017) to generate US\$6.6 billion in the section of beauty and personal care over 2016-2021. Among them, Vietnam with an average annual growth rate of $6.47 \%$ from $2000-2017$ is a strong candidate with small market size but the highest growth rate (Trading Economics).

Figure 3. Breakdown of the global cosmetics market in

2015 by geographic zone

(Source: The Statistics Portal,

2015)

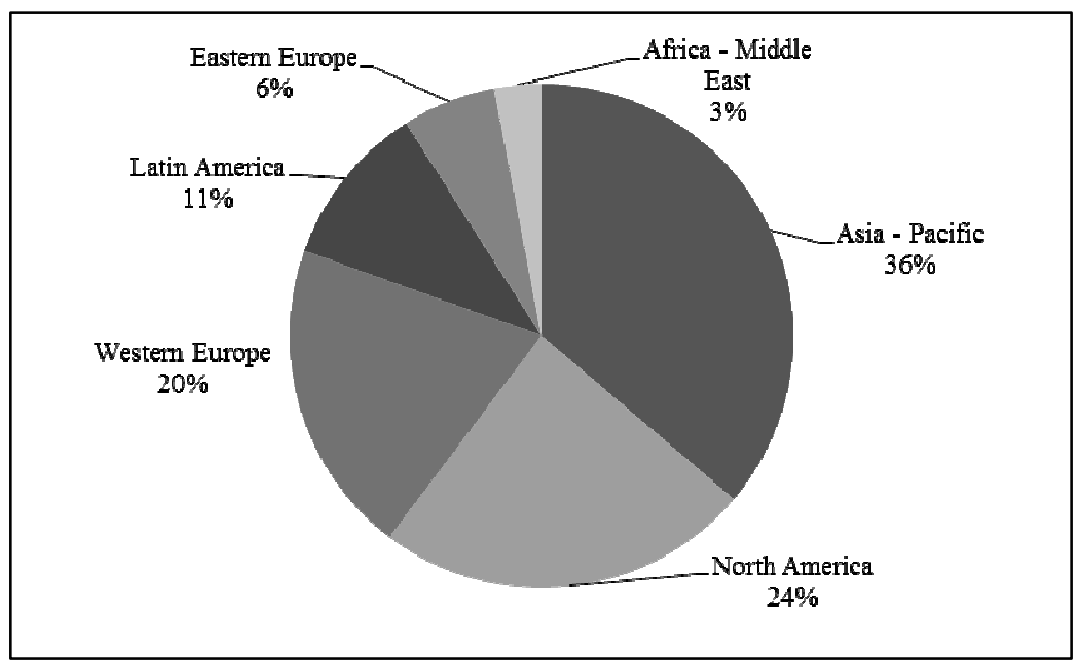

Cosmetic industry is receiving increasing attention as a market of luxury and more necessary goods with increasing growth rate annually. In order to research and manage the appropriate strategies for this sector, managers need to understand the consumer buying behavior toward cosmetics products. Hence this study provides an overview of the global cosmetics markets and its role in Vietnam segment. Thence reviewing the relationship between three factors $\mathrm{COO}$, brand and price with consumer buying behavior toward the facial 
skincare products based on given literature reviews by various scholars. Finally, the findings contribute useful information to the researchers to have a deeper insight of consumer buying behavior so that design the appropriate framework model for development.

\section{Literature review}

\subsection{Cosmetic industry in Vietnam}

In the past, Vietnam is a country with culture and tradition influenced greatly by Chinese, such as Confucianism (Liam, 2006). One thing is easily recognized through Confucianism is Vietnamese women's role in family and society. As well as in prerevolutionary period I Vietnam, women performed most of the essential task for household, could not participate in public activities, particularly business, political office or administration, etc. Later, the revolutionary policies supported the gender equality advocacy but did not get the significant result. However gender relations and attitudes have changed rapidly in recent decades such as typical change of Vietnam Women's Union and the establishment of the Doimoi renovation by the Communist Party in 1986 (Lynellyn, Le, Allison, Le, \& Dang, 2000). It led to improve the roles of Vietnamese women, thus the gender difference has been steadily reduced and they could get into global trade. Today women are more involved in social activities and more educated, thus they get more chances to join workforce and holding more important roles in society, their appearance is more noticed.

After joining World Trade Organization (WTO) in 2007, Vietnam's economy has shifted and changed significantly to be consistent with international commitment. Simultaneously, it has brought Vietnam the opportunities as well as challenges to be integrated in global economy. The largest and premier advantage is that international trade contributes to the increasing export, import and the gross domestic product (GDP) value of Vietnam (Le, 2007). Hence there has been a significant change in consumption of commodities in general and cosmetics products in particular in Vietnam. Besides, the change of Vietnam internally such as demographics, population, culture, lifestyle and interpersonal influences is also the motivation of the cosmetics market's growth. Due to the lack of domestic products, it brings benefit to the oversea cosmetic companies entering in a competitive and potential market like Vietnam. And the skincare sector in this market is predicted to be with a healthy growth which managers should pay attention and maintain (Nguyen \& Sirikhoon, 2008).

Additionally, the economy affects strongly and directly the cosmetic industry in general (Nguyen \& Sirikhoon, 2008). Vietnam is a country with population of above 90 million and stable GDP growth annual, thus Vietnam is one of the large emerging markets and destination of more and more foreign products. Due to the global economic crisis, Vietnam's economy faced many economic problems during the period 2007-2012 (Vuong, 2012). However 2013 was quite a positive year of Vietnam's economy with an increase GDP of 5.42\%. It is the sign of recovery regarding to the government's efforts to bridle inflation and regain economic stability and it is considered with more sustainable growth in the following years. In conjunction with high economic growth and improvement in roles of Vietnamese women, the disposable income is rising and the living standard has also improved dramatically, Vietnamese purchasing power is frequently stronger. Besides, change in policies affected positively to Vietnam commodity market in general and cosmetics market in particular, where cosmetics companies can export cosmetics products into Vietnam freely concluding the testing certification of quality; and cosmetic tax is also reduced. It helps many foreign companies take advantage to enter Vietnam market.

Today nearly 80 percent of Vietnamese women utilize cosmetics and skincare products. In Vietnam, skincare sector is accounted for one third of cosmetics market (Nguyen \& Sirikhoon, 2008).While Vietnam is a country with humid tropical climate and increasing air pollution, the demands for cosmetics products with various functions of skin protection like sunscreen, whitening or anti-aging skincare contribute to the expansion of the diversity of skincare products. Linked to the real cosmetics market in Vietnam currently, due to the lack of domestic products, more than 90 percent of cosmetics products have been imported recently and the import value 
The impacts of country of origin, price, and brand on consumer behavior toward cosmetics products

of cosmetics including beauty, make-up and skincare preparations has increased significantly in recent years

(Figure 4).

Figure 4. Import

value of cosmetics

products into

Vietnam from 2003

to 2012 (Source:

United Commodity

Trade Statistics

Database, 2013)

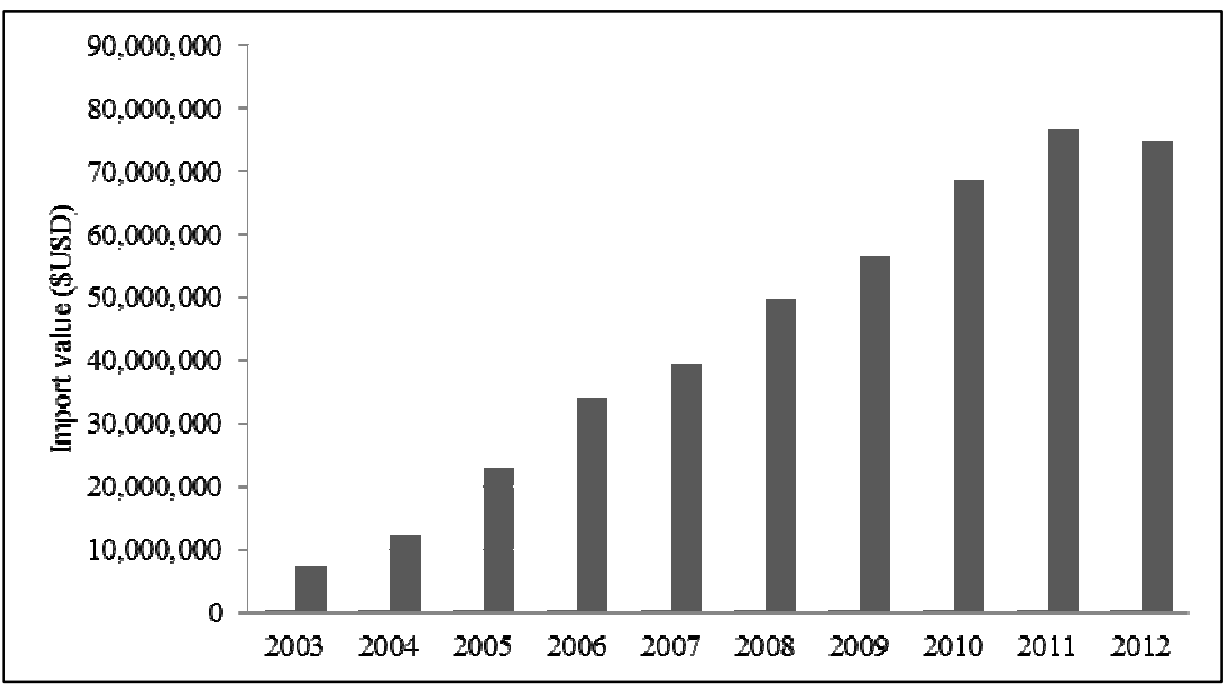

It is the fact that the cosmetics products with $\mathrm{COO}$ from developed countries with high technology and well-known brands are evaluated higher than others. The five largest exporters into Vietnam for few years past are Thailand, Korea, France, Japan and USA with their export values and market share shown in below table.

Table 1

Import value and market share of cosmetics products in 2011-2012

\begin{tabular}{|c|c|c|c|c|c|c|c|}
\hline & \multicolumn{2}{|c|}{2010} & \multicolumn{2}{|c|}{2011} & \multicolumn{2}{|c|}{2012} \\
\hline & & Value (USD) & $\begin{array}{l}\text { Market } \\
\text { share }\end{array}$ & Value (USD) & $\begin{array}{l}\text { Market } \\
\text { share }\end{array}$ & Value (USD) & $\begin{array}{l}\text { Market } \\
\text { share }\end{array}$ \\
\hline 1 & Thailand & $29,725,860$ & $43.40 \%$ & $32,868,594$ & $42.88 \%$ & $26,551,134$ & $35.60 \%$ \\
\hline 2 & Korea & $8,491,900$ & $12.40 \%$ & $10,670,914$ & $13.92 \%$ & $12,845,500$ & $17.22 \%$ \\
\hline 3 & France & $6,176,410$ & $9.02 \%$ & $7,746,568$ & $10.11 \%$ & $7,589,609$ & $10.18 \%$ \\
\hline 4 & Japan & $5,087,450$ & $7.43 \%$ & $5,412,550$ & $7.06 \%$ & $5,962,591$ & $7.99 \%$ \\
\hline 5 & USA & $4,378,210$ & $6.39 \%$ & $4,320,091$ & $5.64 \%$ & $5,931,515$ & $7.95 \%$ \\
\hline & Total & $68,498,680$ & & $76,650,329$ & & $74,583,228$ & \\
\hline
\end{tabular}

Source. United Unions Commodity Trade Statistics Database (2013).

\section{Consumer behavior}

\subsection{Consumer buying behavior}

There is wide spread research on consumer behavior due to increasing growth in trading, the release of abundant new brands and products, intense competition among the companies and growing consumption of goods today. Consumer behavior is absolutely one of the most crucial aspects in marketing research (Suman \& Mansi, 2014). Solomon (1999) gave a definition of consumer behavior as "the process involved when individuals or groups select, purchase, use or dispose of products, services, ideas or experiences to satisfy needs and desires." Gabbott and Hogg (1998) and Blackwell, Miniard, and Engel (2006) also define consumer behavior including activities which describe a way of buying, using and disposing of a person. On the other hand, Schiffman and Kanuk (2000) consider how people make their decision to purchase a product based on their available time, money and efforts. Richards (2009) additionally summed up what affects consumers to purchase a product or service presented to consumer behavior.

The company needs to figure out the reasons that consumers make a particular purchase to understand what motivates and creates consumer purchase decision as well as their buying habits (Ghazali, Othman, Yahva, \& 
Ibrahim, 2008) so that the company can adopt that information into planning marketing strategies to meet consumers' demands (Blackwell et al., 2006). To marketers consumers are treated as the king of market and researchers emphasized consumers as an important determinant for marketing decision and success (Blackwell et al., 2006). Consumers are the central factor weaving realities themselves (Cova \& Remy, 2007) and customer-centric is the strategy bringing organizations success (Blackwell et al., 2006). Consumers are an aggregation of many particular individuals and they are not identical, thus they may make different decisions through a variety of product attributes and the ways they perceive product quality (Ghazali et al., 2008). Consumers' purchases are affected by both external and internal factors and these factors are also divided into two kinds: controllable and uncontrollable by which consumers are affected highly. According to Kotler, Armstrong, Wong and Saunders (2008), four major factors influencing consumer behavior greatly are cultural, social, personal and psychological. The motivation of consumer decision making starts from two types, firstly it is based on consumers' purpose, need or desire called work motivation, it is the reason regarding to product performance which makes consumers achieve goals; and the second one is behavioral or personal motivation which refers to consumers' emotion and feeling when they want to show or express something through the product (Haghshenas, Abedi, Ghorbani, Kamali, \& Harooni 2013; Swaha \& Sritama, 2012).

There are four typical types of consumer behavior aimed to identify how consumers make purchase decision; they are habitual, variety seeking, complex and dissonance reducing behavior (Shaver, 2007). Habitual buying behavior is conducted on regular, habitual and repeatable basis, consumers often have this kind of behavior when they purchase a low-priced product and spend less energy to decide. Consumers often use simple rule, a little research to purchase when they have variety seeking behavior, in this case they like to shop around in the store and try some different products. With complex behavior consumers try to collect as much information as possible to search difference between products; while dissonance reducing decisions also require researching a lot of information but when consumers decide between less different products. Both complex and dissonance reducing behavior are applied when consumers purchase a high value product with high risk.

Many authors developed several models of consumer behavior; most of them contain common stages such as pre-purchase, purchase and post-purchase (Hoyer \& Maclnnis, 2001). The Engel-Kollat-Blackwell (EKB) model which is first mentioned by Engel, Blackwell, and Miniard (1999) has been adopted widely to explain consumer behavior by all relevant influences and outcomes. According to the model, consumer decision making process includes five stages: problem recognition; information search; evaluation of alternatives; decision implementation and post-purchase evaluation. Although the notions of "beauty" from different cultures are not similar, the consumption of cosmetics is related to the global consumer behavior; since the beauty care products are used to meet the demands and desire of consumers.

\subsection{Vietnamese consumer buying behavior}

In contrast with Western countries, the characteristics of Asian cultures are known as collectivism which leads to the interpersonal relationships (James, 1992), and Vietnam is not an exception. It means that utilizing a product reflecting a person's status and class is important; moreover, their purchasing and utilizing are influenced by the reference groups and need to be consistent with social norms. Le and Jolibert (2001) pointed out that these cultural dimensions affect Vietnamese buying behavior significantly. Nevertheless, after the Doimoi period, there has been a change of some these cultural notions in the context of globalization (Le \& Jolibert, 2001). Besides, consumer attitude toward the products imported from various countries is not similar (Cattin, Jolibert, \& Lohnes, 1982). Even for consumers of the same nationality such as Vietnam, attitude and perception of the products may be different significantly from one consumer to another.

After participating on global trade, the markets of all commodities are more open, it facilitates the consumers' choice between more oversea and local products, especially for luxury goods which are principally imported like cosmetics products. Additionally, the socio-economics development in Vietnam led to the high demands of purchasing and higher living standards. The needs of purchasing and utilizing the branded goods by 
The impacts of country of origin, price, and brand on consumer behavior toward cosmetics products

working women is higher, while young generation in Vietnam has had a tendency to foreign brands. The highest class of Vietnamese consumers with highest income prefers well-known and expensive foreign brands regarding to their social status (Le \& Jolibert, 2001). In conclusion, Vietnamese consumers concern more and more brands of the products from foreign countries, especially developed and popular countries with different price levels.

\subsection{Country-of-origin}

Definition of country-of-origin - In the globalization context, there is an increasing competition level in the global markets among the companies with their operations and manufacturability worldwide, as well as increasing presence of foreign goods in national markets. Therefore, the place where the companies manufacture or the country image with which the products are imagined to be related might be the one that consumers use to differentiate and qualify a product. Over the past four decades, the country-of-origin (COO) of a product has been considered to be an important marketing element in many marketplaces.

Samiee (1994) points out that COO represents the country called home country that a company manufacturing products belongs to. Some brands are known to pertain to a certain country, such as IBM belongs to the USA and Sony belongs to Japan. As an informational cue, Zhang (1996) mentions COO as "information pertaining to where a product is made", similarly $\mathrm{COO}$ is also defined as "the country in which the product is made" (Thakor \& Katsanis, 1997). Nevertheless, a product is composed of different ingredients and components from many countries, thus by following the definition of Bilkey and Nes (1982), Han and Terpstra (1988); Ahmed and d'Astous (2004) defines $\mathrm{COO}$ as "the country of manufacture or assembly". Yet citing the country-of-manufacture (COM) synopsis of Samiee, he refers COM, as same as COO, to the last stage of production. Rogers, Kaminski, Schoenbachler, and Gordon (1994) support by assuming that consumers do not distinguish between the locations of manufacture and assembly. Companies can raise consumers' awareness of sourcing through "made in" or "manufactured in" labels (Cai \& Swagler, 2004; Bannister \& Saunders, 1978; Chasin \& Jaffe, 1979). However, nowadays a product might be in a country but designed, assembled or branded etc in another country. Some companies (even operating in cosmetic industry) have established their manufacturing centers in emerging countries for the low cost production, the final products. Thus Phau and Prendergast (1999) define $\mathrm{COO}$ as "the country where corporate headquarters of the company marketing the product or brand is located". And in this study, $\mathrm{COO}$ of products is defined by brands' and companies' headquarter origin, not by country of manufacturing or assembly. This is supported by Johansson, Douglas and Nonka (1985) whom considered COO of the product in regard to the place where the headquarters of the company are located, and it is consistent with the context of cosmetics products.

The influence of country-of-origin on consumer behavior - From an information theoretic perspective, consumers use both intrinsic and extrinsic product cues to evaluate quality of a product (Ulgado \& Lee, 1998; Veale \& Quester, 2009). The intrinsic cues are physical and belong to nature or characteristic of products. For cosmetics, packaging, functional benefit, fragrant, color are the intrinsic cues. On the contrary, extrinsic cues such as brand, price and country of origin are part of product's total image but not part of the physical product and can change. It can be argued that extrinsic cues frequently impact consumers' perceptions (Cai \& Swagler, 2004). And the informational phrase on which this study focuses is the country of origin of a product.

So far there have been abundant studies of $\mathrm{COO}$ to make clear the importance that consumers place on $\mathrm{COO}$, and they come to two opposite conclusions. Most of them indicate that $\mathrm{COO}$ plays a significant role in consumers' product evaluation (Liu \& Johnson, 2005; Laroche, Papadopoulos, Heslop, \& Bergeron, 2002; Agrawal \& Kamakura, 1999; Ahmed \& d'Astous, 1996; Ahmed, Johnson, Ling, Fang \& Hui, 2002; Tse \& Gorn, 1993). The evaluations of the product are based on the positive or negative evaluations of the country with which the product is associated (Hong \& Wyer, 1990; Maheswaran, 1994). This effect is stronger when the product's country image appears negative (Papadopoulos \& Heslop, 1993). In addition, in a review of Bilkey and Nes (1982) numerous previous studies examine the COO effect based on different contexts such as products in general (overall image), classes of products, specific types of products and specific brands, those studies also 
assert that COO clearly influence product evaluations. Only the issue of the extent that COO effect is significant is not determined yet. Whereas other studies conclude that COO may not be an important attribute, it has either no effect or only a very weak effect on consumers' foreign product evaluation (Usunier, 2006; Samie, Shimp, \& Sharma, 2005, Lim \& Darley, 1997; Lim, Darley, \& Summers, 1994; Liefeld, 1993; Ettenson, Wagner, \& Gaeth, 1988; Johansson et al., 1985).

A single-cue approach to country-of-origin - Initially most of studies using $\mathrm{COO}$ as a single cue were carried out, regarding to COO which is the only information offered (Narayana, 1981). Schooler (1965) is the pioneer who examined and concluded that COO does have an impact on consumers' judgments of the product and opened the way for the other future systematic research. However, in single cue studies, this method aims to generate more statistically effects of COO than in multi cues approach and these considerable effects from a single design "might or might not exist in the real world" (Ozsomer \& Cavusgil, 1991; Bilkey \& Nes, 1982). As a result, some scholars state that the influence of $\mathrm{COO}$ might be overemphasized by respondents, therefore it leads to confusing findings (Dinnie, 2003; Verlegh, Steenkamp, \& Meulenberg, 2005; Peterson \& Jolibert, 1995; Nes \& Bilkey, 1993). Besides, consumers' perception on various countries is not the same. If the COO label is regarding to a country with a good image, consumers tend to evaluate it higher and vice versa (Chowdhury, 2001). Likewise specific relationship is found between consumer evaluation of a country's products and that country's economic development by Roth and Romeo (1992). Consumers in emerging countries are researched to prefer products from developed countries to developing countries (Shenge, 2010). Eventually, COO is a crucial dimension in examining Vietnamese consumers' evaluation of the category of cosmetic products because firstly, Vietnam is a developing country where consumers would rather use imported and foreign products (Ahmed \& d'Astous, 2004; Zhang, 1996); secondly, COO effects are stronger on "luxury" products than "necessity" products (Piron, 2000), as discussed earlier, cosmetics resembles a luxury product.

A multi-cue approach to country-of-origin - In order to reconcile those arguments within single cue studies, as well as consider the issue in real market situation that consumers' purchase behavior depends on not only COO image itself but also in conjunction with other cues, the development from simple single cue toward a multi-attribute approach through increasing volume of $\mathrm{COO}$ research has been recently applied. Although Peterson and Jolibert (1995) state that the impact of COO on product evaluation using multi-cue approach is less significant than using single cue COO, according to Johansson et al. (1985) and Hong and Wyer (1989) consumers still place $\mathrm{COO}$ along with the other essential attributes in consumers' product evaluation and purchase decision. Much research was conducted to determine the relative importance of COO as one of many potential cues (Thorelli, Lim, \& Jongsuk, 1989; Tse \& Gorn, 1993) and various conclusions were given. Schweiger and Strebinger (1997) suggested that COO impacts greatly on product evaluation despite the presence of other attributes. Chike Okechukwu (1994) furthermore confirmed the importance of COO image by adopting a conjoint analysis and showed that $\mathrm{COO}$ was classified into one of the most important attributes in preference evaluation. However, there are numerous debated findings of the ordinal arrangement of COO's importance to consumer behavior in context of investigating COO image together with the other product attributes such as brand, price, quality and warranty (Ahmed \& d'Astous \&, 1999; Ettenson et al., 1988; Fischer \& Byron, 1997; Wall, Liefeld, \& Heslop, 1991; Chike, 1994).

On the other hand, as stated by Ahmed and d'Astous (1992) before, COO is not evaluated as an important indicator in consumers' purchasing decision. In the study of impact of extrinsic cues on consumer evaluation of beautification products, Parvin and Chowdhury (2006) implied that brand image, perceived quality and COO image all influence positively and significantly on beautification product evaluation but price does not. This study primarily is aimed to reveal the findings by a multi-cue approach of $\mathrm{COO}$ with brand and price of facial skincare products. In terms of multi-cue, general country attributes, general product attributes and specific product attributes are known to be statistically significant in influencing purchase intentions (Yaprak, 1978). A multi-cue list which includes common attributes such as price, quality, brand name, warranty, and COO, etc. is generally offered in most of studies (Zhang, 1996; Johansson, Ronkainen, \& Czinkota, 1994). Besides, gender, income, education and sojourn, etc. are also listed as variables affecting on how consumers evaluate products 
The impacts of country of origin, price, and brand on consumer behavior toward cosmetics products

(Josiassen, Lukas, \& Whitwell, 2008).

Many scholars have researched the influence of the factors toward COO, this enhances the determination of the importance that consumers place on COO image in evaluating products. The most popular ones are two context-specific factors: Product familiarity and product involvement. The result is shown that considering COO as a crucial cue in consumers' evaluation of the product, product familiarity did not decrease its importance or reliance (Schaefer, 1997); additionally, when consumers are less familiar with the product, COO is more important for them to evaluate it (Hong \& Toner, 1989; Insch \& Mcbride, 2004; Johansson et al., 1985; Li, Murray \& Scott, 2000 \& Josiassen et al., 2008). As reported by Laroche, Papadopoulos, Heslop and Mourali (2005), consumers use COO image as an indirect indicator to evaluate the product when they have low product knowledge; hence Schaefer (1997) indicates that the more consumers are provided with knowledge of the product, the more they are sensitive to a product's COO. Similarly, when consumers are less involved with the product, $\mathrm{COO}$ image becomes an important informational cue on which consumers base their product decisions on (Kinra, 2006; Verlegh et al., 2005; Zafar, Johnson, Yang, Fatt, Teng, \& Boon, 2004; Batra, Ramaswamy, Alden, Steenkamp, \& Ramachander, 2000; Gurhan \& Maheswaran, 2000; Maheswaran, 1994; Han, 1989). In general, consumers know less about and low involved with the product, COO image plays a more powerful role in consumers' purchasing behavior. In evaluating the product together with other cues, the role of COO in consumers' decision making process is divided into two ways: the halo and the summary construct (Han, 1989; Hong \& Wyer, 1989). The halo effect will be presented when consumers have little knowledge about the product, or they are not familiar with the product. In contrast, consumers are familiar with the country's products, COO image serving as a halo construct will not have significant effect, but summary construct does have.

\subsection{Brand}

Definition of brand - In addition to COO and price, brand is an additional extrinsic cue used in consumers' product evaluation and purchase decision making. Brand is defined by Kotler, Armstrong, Saunders and Wong (1999) as a "name, term, sign, symbol or design, or a combination of these" which consumers use to recognize and discriminate a brand from other companies' one. Feldwick (1996) developed further sense through Kotler's definition that a brand shows the company's assurance in fulfilling consumers' needs. That is to say, both Kotler and Feldwick created a perception of brand as a deep connection between company and consumer. Gordon (2002) has recently affirmed that brand represents how a promise of what consumers can expect from a product or a service of the company can be enforceable.

The influence of brand on consumer behavior - In modern-day, marketing researchers evaluate brands as one of the most worthwhile assets that the company owns (Neumeier, 2006), consumers accordingly use brands which combine both tangible and intangible values to create a set of brand awareness to differentiate the brand from another (Hankinson \& Cowking, 1993) as well as a set of brand association to maintain consumers' beliefs. Brand awareness is therein described as consumers' ability based on prior experience to differentiate and recognize a brand from another's brand available for purchase (Aaker, 1991; Keller, 1993); Shrimp (2007) concluded that a brand with higher level of awareness would become more familiar and reputable to consumers; and consumers' brand awareness to foreign brands is higher than domestic brands (Lee, Knight, \& Kim, 2008; Bhardwaj, Kumar, \& Kim, 2009). Whereas brand association reflects consumers' beliefs to a specific brand, which brand managers try to manage and keep up (Aaker, 1996; Keller, 1993). That nature of a brand helps separate a brand from an ordinary product. Because according to King (1991), he notified two distinct definitions between the product and brand, in which product refers to tangible asset that is likely to be copied by the competitors and brand is an intangible asset that is distinctive and everlasting. Thus it is no wonder that brand is asserted as core identity of a product. It leads to the consequence, similarly to product, that perceived quality also plays an important part of brand perception (Lee et al., 2008). When consumers perceive the difference among the brands, they will perceive unlike quality too; besides familiarity with a brand name partly impacts on consumers' quality evaluation (Xiaoling, Leeva, Charlene, \& Jun, 2008) and this recognition varies through amount of effects by different brands (Kurt, 2005). 
Brands are the aggregation of all images about a specific company or product that consumers have and brands may take the place of numerous attributes such as quality (Xiaoling et al., 2008; Lockshin, Rasmussen, \& Cleary, 2000), thus brands play a significant role to consumers' evaluation and take part in consumers' choice process (Hoyer \& Brown, 1990; Dillion, Madden, Kirmani, \& Mukherjee, 2001). Many scholars demonstrated that consumers perceive global brands with higher price and better quality (Cattin et al., 1982; Tse \& Gorn, 1993; Samiee, 1994; Thakor \& Lavack, 2003); as a result, global brands effect positively on consumers' assessment. In this study, consumer behavior will be suggested to be experimented with the facial skincare products of perceived global brands from four countries France, Korea, Japan and the USA.

Above all, aiming to attract consumers, marketers sought to evaluate, recognize and take advantage of brand as a helpful instrumental marketing tool. When consumers do not have any specific ideas or lack in knowledge about the product, they can rely on brands as a proxy to make judgments for making purchase decision (Jacoby, Olson \& Haddrock, 1971; Dodds, Monroe, \& Grewal, 1991; Bhaskaran \& Sukumaran, 2007). Then if a brand builds up its prestige and consumers' loyalty, consumers will appreciate with favorable perception of that brand (Parvin \& Chowdhury, 2006). Moreover, a popular brand name not only reduces consumers' perceived risk and information searching costs but also achieves position evaluation toward that brand, especially when consumers feel uncertain about the product (Parvin \& Chowdhury, 2006; Montgomery \& Wernerfelt, 1992; Erdem \& Swait, 1998). And sometimes consumers consider brand image as a symbol of social status, it also provide consumers a motivation to own that brand (Parvin \& Chowdhury, 2006).

If price factor, similarly to $\mathrm{COO}$ in serving as a halo, brand like $\mathrm{COO}$ can be viewed as a summary construct (Jacoby et al., 1971). Brand containing the attributes as a summary construct may give consumers more information of the product than price parameter (Jacoby, George \& Jacqueline, 1977); furthermore, because a brand with the same $\mathrm{COO}$ have very similar product attributes, consumers may imagine and evaluate the product based on either brand or COO (Han, 1989).

The difference between the influences of country-of-origin and brand on consumer behavior - According to Tse and Gorn (1993) and d'Astous and Ahmed (1996), consumers are aware of their product evaluation and purchase decision through both brand name and location where the product originates, those belong to important intangible assets (Chung, 1995). Haubl (1997) likewise pointed out that these two factors also perform in consumers purchase intention for luxury products; in this study, the luxury one regards to cosmetic products. In details, Parvin and Chowdhury (2006) concluded that "three extrinsic cues: brand image, perceived quality and perceived $\mathrm{COO}$ have positive and significant influence on consumers' brand evaluation of beautification brands".

In that respect, $\mathrm{COO}$ can influence consumers' recognition toward a brand either positively or negatively. The prestigious brand names are often tied with their favorable country images (Bhaskaran \& Sukumaran, 2007). A brand name with prestige and reputation may make up for an unfavorable $\mathrm{COO}$ image if price factor does not involve (Tse \& Lee, 1993; Ahmed, d'Astous, \& Zouiten, 1993), e.g., between a Sony product is originated in Japan and one is manufactured in Hong Kong, consumers somehow still perceive the product as a Sony brand though Hong Kong brings a lower image than Japan. But if the product is made in a country with negative image, it may reduce the influence of its positive brand name (Johansson \& Nebenzahl, 1986).

A brand may affect consumers' behaviors more clearly than COO image (Thakor \& Pachetu, 1997; Leclerc, Schmitt \& Dube, 1994). A product with a powerful name may diminish consumers' beliefs and recognizable ability (Papadopoulos \& Heslop, 1993). Brands occasionally even take place of COO attributes due to its association with a particular country (Samiee, 1994). More clear evidences about the relationship between brand and $\mathrm{COO}$ are that a brand may develop its popularity by itself without being supported by a favorable $\mathrm{COO}$ image while a country name only brings consumers a positive judgment from the positive country (Chung, 1995). 
Definition of price - Price is defined as what consumers are charged for a service rendered or goods supplied by Perreault and McCarthy (1993). Consumers perceive price as an extrinsic cue for most of the products in every context (Ophuis \& Trijp, 1995), price consequently assumes an important role among other market variables (Lichtenstein, Ridgway \& Netemeyer, 1993). The role of price in product evaluation is similar to $\mathrm{COO}$ image that it serves as a proxy to replace or enhance other information. Price is more likely to be used when consumers evaluate the product in these situations: the information of the product is lacking (Jacoby et al., 1971); they are unfamiliar with the product (Monroe, 1976); and information about purchase context is lacking (Belk, 1975; Erickson \& Johansson, 1985). In the study about impact of product price and quality taken place in Pakistan, Rajput, Kalhoro, and Wasif (2012) revealed that price has a significant and positive relationship with consumer buying behavior.

The influence of price on consumer behavior - At first a great number of researches have been conducted into the price-quality relationship, most of which are examined under the situations that different prices are the only information applied to respondents (McConnell, 1968; Olander, 1969; Tull, Boring, \& Gonsior, 1964) and a positive price-quality relationship was found. In other words, consumers would take price as an indicator or signal to rate the product quality (Erikson \& Johansson, 1985; Parvin \& Chowdhury, 2006) because they believe that the interaction between supply and demand is shown in and contributes to formation of price (Grewal, Krishnan, Baker, \& Borin, 1998). It is acknowledged in detail that higher price suggests the better quality or higher value (Knauth, 1949). However, Chang and Wildt (1998) emphasized in the condition that price is considered as the only available information for consumers or a single-cue access, it would impact significantly on consumers' perceived quality; i.e., price-level perceptions in single studies had a direct negative impact and an indirect positive impact on consumers' purchase intentions through their perceived quality (Erickson \& Johansson, 1985). Besides, in multi-cue studies including price with other variables (Broome \& Edward, 1966; Gardner, 1970; Jacoby et al., 1971; Rao, 1970; Saphiro, 1970; Stafford \& Enis, 1969), the positive price-quality relationship is only reflected in some; e.g, in the category of beautification products, Parvin and Chowdhury (2006) found that brand image, perceived quality and COO image does influence on consumers' evaluation but only price. Eventually, relying on two following reasons, it infers that consumers are aware of price as an indicator in both purchase decision making and product quality perceptions. Firstly, there is more research in the importance of price in perceiving product quality than any other factors (Dodds et al., 1991; Swan, 1974; Wheatley \& Chiu, 1977; Zeithaml, 1988). Secondly, in the classical economic theory, it is explained by default that consumers expect and act to receive the maximum value from the product with their money (Kotler, 1972; Lilien \& Kotler, 1983).

Price perception is affected by not only internal but also external factors (Mendoza \& Baines, 2012). Some authors listed brand familiarity (Abhijit, 1992), price consciousness (Alford \& Biswas, 2002), and attitudes and prior experiences (Rosa, 2004) as the internal factors. External factors contain reference prices (Kumar, Karande, \& Reinartz, 1998), store choice (Tang, Bell, \& Ho, 2001), asymmetries of information (Stephan, 2008) and emotions (Stephan, 2011). Based on the broad focus on price perception formation, consumers' price perception in this study is only considered from the psychology and marketing facets of the whole price concept.

The difference between the influences of country-of-origin and price on consumer behavior - Ahmed, d'Astous, and Zouiten (1993) identified a significant interaction between price and COO but not between price and brand. On this premise the necessity of price concessions for a poor image will make sense (Johansson \& Nebenzahl, 1986; Nebenzahl \& Jaffe, 1993); in addition, if the COO holds a positive image, it will affect and reduce consumers' attention to the notion that higher price with better product quality (Bhaskaran \& Sukumaran, 2007). Thus price plays partly role in changing COO image of the product. Nevertheless, White and Cundiff (1978) initially claimed that no interaction between price and COO was found in more developed countries. While Okechuku and Onyemah (1999) indicated that COO is significantly more important than price and other attributes, Ettenson et al. (1988) and Johansson et al. (1985) suggested a contrary conclusion that price and 
quality affect consumers' product evaluation more significantly than $\mathrm{COO}$ information. As mentioned before, consumers tend to prefer products from developed countries rather than emerging countries, they may consequently be more willing to pay a higher price for the product from more developed countries than from emerging countries (Shenge, 2010). On the contrary, consumers expect a lower price for the product of which COO image comes from less favorable countries (Nebenzahk \& Jaffe, 1996).

\section{Conclusions}

By the fact that increasing importance and popularity of cosmetics take more and more interests, especially in modern life, the study gives knowledge of potential Vietnam cosmetics market, a deeper insight of Vietnamese consumer behavior, and possibile use and appliance of factors $\mathrm{COO}$, brand and price regarding to the sector of cosmetic industry. Based on statistical data and related systematic literature, this review identified as the main ideas of consumer behavior and the impacts of three extrinsic factors, which partly introduce and motivate both researchers and managers to generate a series of research models and applied papers. During the last four decades, though it has come up with appearance and increase of both empirical and conceptual research activities of the mentioned issues, they still need to be developed in another context of various modern society, modern technology, or under more open policies toward the products in Vietnam.

\subsection{Limitations}

First, it is indicated in many research that consumer buying decision is affected by varied factors which are both internal and external factors; however in this study, the identified relevant literature is limited and only focused on specific areas cosmetic industry and feature only three extrinsic factors $\mathrm{COO}$, brand and price. Second, the reported data in Vietnam in the study was published till the year of 2013. Yet the growth of market in particular and specific literature in general are continuously increasing, therefore it requires a frequent up-to-date information, especially in modern context of competitive benefits and advantages. Third, as mentioned in Vietnam market, it does exist a good chance for foreigner exporters of cosmetics, also the specific reviews of consumer perception of $\mathrm{COO}$ as the nation of products which mostly comes from abroad. The evaluation of products coming from domestic market should be involved also. And last, due to the feature of beautification products, the nature of $\mathrm{COO}$ and $\mathrm{COM}$ were established as country the headquarter company who stands for the brand of products. For the companies operating in many countries for different stages of manufacturing, and the characteristics of products (eg. assembly), these two notions and effects may be distinguished and serepratedly examined.

\subsection{Future Research}

This review may offer opportunities for additional research in the future. In the same Vietnam market, there are still chances to implement the upcoming generated papers. With selected market characteristics which include more than 90 percent cosmetics imported from foreign countries (United Commodity Trade Statistics Database, 2013), different COO may cause various product evaluation. It should be compared to make clear of the effects of $\mathrm{COO}$ from developed countries and developing countries regarding to the findings of Shenge (2010). And also whether the factor COO, price and brand can be the alternative of each other or not when consumers tend to perceive the product quality in the concept of lacking information (Han, 1989). Furthermore, not only in Vietnam but also in global cosmetic industry in general, cosmetics industry is vast in scope due to its diverse categories of products. Thus it is suggested to develop both empirical and theoritical research in a specific aspect of the sector. Limitations encountered during research that consumer behavior should be under investigation comprising of addtional factors.

\section{References}

Aaker, D. A. (1991). Managing brand equity. New York, NY: The Free Press. 
The impacts of country of origin, price, and brand on consumer behavior toward cosmetics products

Aaker, D. A. (1996). Building strong brands. New York, NY: The Free Press.

Abhijit, B. (1992). The moderating role of brand familiarity in reference price perceptions. Journal of Business Research, 25(3), 251-262. https://doi.org/10.1016/0148-2963(92)90033-8

Agrawal, J., \& Kamakura, W. A. (1999). Country of origin: a competitive advantage. International Journal of Research in Marketing, 16(4), 255-267. https://doi.org/10.1016/S0167-8116(99)00017-8

Ahmed, S. A. \& d'Astous, A. (1996). Country of origin and brand effects: a multi-dimensional and multi-attribute study. Journal of International Consumer Marketing, 9(2), 93-115. https://doi.org/10.1300/J046v09n02_05

Ahmed, S. A., \& d'Astous, A. (2004). Perceptions of countries as producers of consumer goods: A T-shirt study in China. Journal of Fashion Marketing and Management, 8(2), 188-202. https://doi.org/10.1108/13612020410537889

Ahmed, S. A., d'Astous, A., \& Zouiten.S (1993). Personality variables in the made-in concept. In N. G. Papadopoulos \& L. A. Heslop (Eds.), Product-country images: Impact and role in international marketing (pp. 197-222), New York: International Business Press.

Ahmed, Z. U., Johnson, J. P., Ling, C.P., Fang, T. W., \& Hui, A. K. (2002). Country-of-origin and brand effects on consumers' evaluations of cruise lines. International Marketing Review, 19(2), 279-303. https://doi.org/10.1108/02651330210430703

Alford, B. L., \& Biswas, A. (2002).The effects of discount level, price consciousness and sale proneness on consumers' price perception and behavioural intention. Journal of Business Research, 55(9), 775-783. https://doi.org/10.1016/S0148-2963(00)00214-9

Anderson, P. (2014). What age is too young for make up. Retrieved from http://www.mascaraforsensitiveeyes.com/what-age-is-too-young-for-make-up/

Bannister, J.P., \& Saunders, J. A. (1978). UK consumers' attitudes towards imports: The measurement of national stereotype image. European Journal of Marketing, 12(8), 562-570. https://doi.org/10.1108/EUM0000000004982

Batra, R., Ramaswamy, V., Alden, D. L., Steenkamp, J.E.M., \& Ramachander, S. (2000). Effects of brand local and nonlocal origin on consumer attitude in developing countries. Journal of Consumer Psychology, 9(2), 83-95. https://doi.org/10.1207/S15327663JCP0902_3

Belk, R. W. (1975). Situational variables and consumer behavior. Journal of Consumer Research, 2, 157-164. https://doi.org/10.1086/208627

Bhardwaj, V., Kumar, A., \& Kim, Y. K. (2009). Brand analyses of U.S. global and local brands in India: The Case of Levi's. Journal of Global Marketing, 23(1), 80-94. https://doi.org/10.1080/08911760903442226

Bhaskaran, S., Sukumaran, N. (2007). Contextual and methodological issues in COO studies. Marketing Intelligence \& Planning, 25(1), 66-81. https://doi.org/10.1108/02634500710722407

Bilkey, W. J., \& Nes, E. (1982). Country-of-origin effects on product evaluations. Journal of International Business Studies, spring/summer, 89-99. https://doi.org/10.1057/palgrave.jibs.8490539

Blackwell, R. D., Miniard, P. W., \& Engel, J. F. (2006). Consumer behavior. Mason, OH: Thomson.

Broome, C., \& Edward, S. (1966). Experimental determination of the effect of price and market-standing information on consumers' brand preferences proceedings. Fall Conference American Marketing Association, pp. 520-531.

Cai, Y., \& Swagler, R. (2004). Country-of-origin effects on consumers' willingness to buy foreign products: an experiment in consumer decision making. Consumer Interests Annual, 50, 98-105.

Cattin, P. J., Jolibert, A., \& Lohnes, C. (1982). A cross-cultural study of "made-in" concepts. Journal of International Business Studies, 13(3), 131-141. https://doi.org/10.1057/palgrave.jibs.8490564

Chang, Z., \& Wildt, R. (1998). Impact of product information on the use of price as a quality cue. Psychology \& Marketing, 13(1), 55-75. https://doi.org/10.1002/(SICI)1520-6793(199601)13:1<55::AID-MAR4>3.0.CO;2-O

Chasin, J., \& Jaffe, E. (1979). Industrial buyer attitudes towards goods made in eastern Europe. Columbia Journal of World Business, 14(summer), 74-81.

Chike, O. (1994). The importance of product country of origin: A conjoint analysis of the United States, Canada, 
Germany and The Netherlands. European Journal of Marketing, February, 5-19.

Chowdhury, M. H. K. (2001). Country-of-origin: The concept and its measurement. Asian Academy of Management Proceedings, 4(2), 55-63.

Chung, K. K. (1995). Brand popularity and country image in global competition: managerial implications. Journal of Product \& Brand Management, 4(5), 21-33. https://doi.org/10.1108/10610429510103818

Cova, V., \& Rémy, E. (2007). I feel good - Who needs the market? Struggling and having fun with consumer driven experiences. In Antonella, C., \& Bernard, C. (Ed.), Consuming Experience (pp. 17-33). New York, NY: Routledge.

D'astous, A., \& Ahmed, S. A. (1992). Multi-cue evaluation of made-in concept: a conjoint analysis study in Belgium. Journal of Euro-Marketing, 2(1), 9-29. https://doi.org/10.1300/J037v02n01_03

d'Astous, A., \& Ahmed, S. A. (1999). The importance of country images in the formation of consumer product perceptions. International Marketing Journal, 16(2), 8-25. https://doi.org/10.1108/02651339910267772

Dillion, W. R., Madden, T. J., Kirmani, A., \& Mukherjee, S. (2001). Understanding what's in a brand rating: A model for assessing brand and attribute effects and their relationship to brand equity. Journal of Marketing Research, 38(4), 415-429. https://doi.org/10.1509/jmkr.38.4.415.18910

Dinnie, K. (2003). Country of origin 1965-2004: A literature review. Journal of Customer Behaviour, 3(2), 165-213. https://doi.org/10.1362/1475392041829537

Dodds, W. B., Monroe, K. B., \& Grewal, D. (1991).Effects of price, brand, and store information on buyers' product evaluation. Journal of Marketing Research, 28(8), 307-319. https://doi.org/10.2307/3172866

Engel, J. F., Blackwell, R. D., \& Miniard, P. W. (1999). Consumer behavior (6th ed.). Chicago, MI: Dryden Press.

Erdem, T., \& Swait, J. (1998). Brand equity as a signalling phenomenon. Journal of Consumer Psychology, 7(2), 131-157. https://doi.org/10.1207/s15327663jcp0702_02

Erickson, G. M., \& Johansson, J. K. (1985). The role of price in multi-attribute product evaluations. Journal of Consumer Research, 12(9), 195-199. https://doi.org/10.1086/208508

Ettenson, R., Wagner, J., \& Gaeth, G. (1988). Evaluating the effect of country of origin and the "made in the USA" campaign: a conjoint approach. Journal of Retailing, 64(1), 85-100.

Feldwick, P. (1996). What is brand equity anyway and how do you measure it. Journal of the Marketing Research Society, 38, 85-104.

Fischer, W. C., \& Byron, P. (1997). Buy Australia made. Journal of Consumer Policy, 20(1), 88-97. https://doi.org/10.1023/A:1006856704983

Gabbott, M., \& Hogg, G. (1998). Consumers and services. Chichester: John Wiley \& Sons.

Gardner, D. (1970). An Experimental investigation of the price-quality relationship. Journal of Retailing, 46, $25-41$.

Ghazali, M., Othman M. Said, Yahya, A. Z., \& Ibrahim, M. S. (2008). Products and country of origin effects: The Malaysian consumers' perception. International Review of Business Research Papers, 4(2), 91-102.

Gordon, W. (2002).Minding your brand manners. Journal of Marketing Management, 11(5), 18-20.

Grewal, D., Krishnan, R., Baker, J., \& Borin, N. A. (1998). The effect of store name, brand name and price discounts on consumers' evaluations and purchase intentions. Journal of Retailing, 74(3), 331-352. https://doi.org/10.1016/S0022-4359(99)80099-2

Gurhan, C. Z., \& Maheswaran, D. (2000). Determinants of country-of-origin evaluations. Journal of Consumer Research, 27(1), 96-108. https://doi.org/10.1086/314311

Haghshenas, L., Abedi, A., Ghorbani, E., Kamali, A., \& Harooni, M. (2013). Review consumer behavior and factors affecting on purchasing decisions. Singaporean Journal of Business Economics and Management Studies, 1(10), 17-23. https://doi.org/10.12816/0003798

Han, M., \& Terpstra, V. (1988). Country-of-origin effects for uni-national and bi-national. Journal of International Business Studies, 19(2), 235-255. https://doi.org/10.1057/palgrave.jibs.8490379

Han, M. (1989). Country image: halo or summary construct? Journal of Marketing Research, 26(2), 222-229. https://doi.org/10.2307/3172608

Hankinson, G. \& Cowking, P. (1993). Branding in action. McGraw-Hill Marketing for Professionals Series. 
The impacts of country of origin, price, and brand on consumer behavior toward cosmetics products

Cambridge, McGraw-Hill.

Haubl, G. (1997). A cross national investigation of the effects of country of origin and brand name on the evaluation of a new car. International Marketing Review, 13(5), 76-97.

Hong, S. T., \& Wyer Jr, R. S. (1989). Effects of country of origin and product attribute information on product evaluation: An information processing perspective. Journal of Consumer Research, 16, 175-187. https://doi.org/10.1108/02651339610131405

Hong, S. T., \& Wyer Jr, R. S. (1990). Determinants of product evaluation: Effects of the time interval between knowledge of a product's country-of-origin and information about its specific attributes. Journal of Consumer Research, 17, 277-288. https://doi.org/10.1086/209206

Hong, S. T., \& Toner, J. F. (1989). Are there gender differences in the use of country-of-origin information in the evaluation of products? Advances in Consumer Research, 16(1), 468-472. https://doi.org/10.1086/208557

Hoyer, W. D., \& Brown, S. P. (1990). Effects of brand awareness on choice for a common, repeated-purchase product. Journal of Consumer Research, 17(2), 141-148. https://doi.org/10.1086/208544

Hoyer, W. D., \& Maclnnis, D. J. (2001). Consumer behaviour. Boston: Houghton Mifflin.

Insch, G. S. \& Mcbride, J. B. (2004). The impact of country-of-origin cues on customer perceptions of product quality: a binational test of the decomposed country-of-origin construct. Journal of Business Research, 57(3), 256-265. https://doi.org/10.1016/S0148-2963(02)00323-5

Jacoby, J., George, J. S., \& Jacqueline, B. S. (1977). Information acquisition behavior in brand choice situations. Journal of Consumer Research, 3, 209-216. https://doi.org/10.1086/208669

Jacoby, J., Olson, J. C., \& Haddock, R. A. (1971). Price, brand name and product composition characteristics as determinants of perceived quality. Journal of Applied Psychology, 55(6), 570-579. https://doi.org/10.1037/h0032045

James, D. L. (1992). Don't think about winning. Across the Board, 29(4), 49-51.

Johansson, J. K., \& Nebenzahl, I. D. (1986). Multinational production: Effect on brand value. Journal of International Business Studies, 17(3), 101-26. https://doi.org/10.1057/palgrave.jibs.8490861

Johansson, J. K., Douglas, S. P., \& Nonka, I. (1985). Assessing the impact of country of origin on product evaluation: A new methodological perspective. Journal of Marketing Research, 22(4), 388-96. https://doi.org/10.2307/3151584

Johansson, J. K., Ronkainen, I. A., \& Czinkota, M. R. (1994). Negative country of origin effects: The case of the New Russia. Journal of International Business Studies, 25(1), 157-176. https://doi.org/10.1057/palgrave.jibs.8490197

Josiassen, A., Lukas, B. A., \& Whitwell, G. (2008). COO contingencies: competing perspectives on product familiarity and product involvement. International Marketing Review, 25(4), 423-440. https://doi.org/10.1108/02651330810887477

Keller, K. L. (1993). Conceptualizing measuring, and managing consumer based brand equity. Journal of Marketing, 57(1), 1-22. https://doi.org/10.1080/0267257X.1991.9964136

King, S (1991). Brand building in the 1900's. Journal of Marketing Management, 9, 3-13. https://doi.org/10.1080/0267257X.1991.9964136

Kinra, N. (2006). The effect of country-of-origin on foreign brand names in the Indian market. Marketing Intelligence \& Planning, 24(1), 15-30. https://doi.org/10.1108/02634500610641534

Knauth, O. (1949). Considerations in the setting of retail prices. Journal of Marketing, 14 (7), 1-12. https://doi.org/10.2307/1247167

Kotler, P. (1972). A generic concept of marketing. Journal of Marketing, 36(2), 46-54. https://doi.org/10.2307/1250977

Kotler, P., Armstrong, G., Saunders, J., \& Wong, V. (1999). Principles of marketing (2nd European Edition ed.). Upper Saddle River: Prentice Hall Inc.

Kotler, P., Armstrong, G., Wong, V., \& Saunders, J. (2008). Principles of marketing (5th European Edition ed.), Pearson Education Limited.

Kumar, V., Karande, K., \& Reinartz, W. J. (1998). The impact of internal and external reference prices on brand 
choice: The moderating role of contextual variables. Journal of Retailing, 74(3), 401-426. https://doi.org/10.1016/S0022-4359(99)80102-X

Kurt, V. M. (2005). Branding and its impact on the consumer purchase decision making process. Retrieved from http://zh.scribd.com/doc/16355275/Thesis-Branding-Its-Impact-on-the-Consumer-Decision-Making-Pro cess-iTunes-Case-Study-Dec-2005

Laroche, M., Papadopoulos, N., Heslop, L. A. \& Mourali, M. (2005). The influence of country image structure on consumer evaluations of foreign products. International Marketing Review, 22(1), 96-115. https://doi.org/10.1108/02651330510581190

Laroche, M., Papadopoulos, N., Heslop, L., \& Bergeron, J. (2002). Effects of sub cultural differences on country and product evaluations. Journal of Consumer Behaviour, 2(3), 232-247. https://doi.org/10.1002/cb.104

Le, D. D. (2007). Advantages, challenges and actions of Vietnam as a WTO member. Vietnam Economic Review, 7(155), 21-25.

Le T. M., \& Jolibert A. (2001). Advertising practice in a transitional economy: An examination of advertising industry in Vietnam. Retrieved from www.sbaer.uca.edu/research/sma/2001/34.pdf

Leclerc, F., Schmitt, B. H., \& Dube, L. (1994). Foreign branding and its effects on product perception and attitudes. Journal of Marketing Research, 31(2), 263-270. https://doi.org/10.2307/3152198

Lee, M. Y., Knight, D., \& Kim, Y. K. (2008). Brand analysis of a U.S. global brand in comparison with domestic brands. Journal of Product \& Brand Management, 17(3), 163-174. https://doi.org/10.1108/10610420810875089

Li, Z. G., Murray, L. W., \& Scott, D. (2000). Global sourcing, multiple country-of-origin facets and consumer reactions. Journal of Business Research, 47(2), 121-133. https://doi.org/10.1016/S0148-2963(98)00061-7

Liam, C. K. (2006). "Confucianism" in Vietnam: A state of the field essay. Journal of Vietnamese studies, 1(1), 314-370.

Lichtenstein, D., Ridgway, N., \& Netemeyer, R. (1993). Price perceptions and consumer shopping behavior: A field study. Journal of Marketing Research, 30(2), 234-246. https://doi.org/10.2307/3172830

Liefeld, J.P. (1993). Consumer use of country-of-origin information in product evaluations: evidence from experiments. In Papadopoulos, N. \& Heslop, L.A. (Eds.), Product-country image: Impact and role in international marketing (pp. 117-56). New York, NY: International Business Press.

Lilien, G. L., \& Kotler, P. (1983). Marketing decision making: A model-building approach. In New York: Harper \& Row. Kotler P 1972. A generic concept of marketing. Journal of Marketing, 36, 49-54.

Lim, J. S., Darley, W. K., \& Summers, J. O. (1994). An assessment of country of origin effects under alternative presentation formats. Journal of the Academy of Marketing Science, 22(3), 274-82. https://doi.org/10.1177/0092070394223008

Lim, J. S., \& Darley, W. K. (1997). An assessment of demand artefacts in country-of-origin studies using three alternatives. International Marketing Review, 14(4), 201-217. https://doi.org/10.1080/00913367.2005.10639183

Liu, S. S., \& Johnson, K. F. (2005). The automatic country-of-origin effects on brand judgments. Journal of Advertising, 34(1), 87-97. https://doi.org/10.1080/00913367.2005.10639183

Lockshin, L., Rasmussen, M., \& Cleary, F. (2000). The nature and roles of a wine brand.Australia and New Zealand Wine Industry Journal, 15(4), 17-24.

Lopaciuk, A., \& Loboda, M. (2013). Global beauty industry trends in the $21^{\text {st }}$ industry. In ToKnowPress, Active Citizenship by Knowledge Management \& Innovation: Proceedings of the Management, Knowledge and Learning International Conference (pp. 1079-1087). Zadar, Croatia.

Lynellyn, D. L., Le, N. H., Allison, T., Le, T. P. M., \& Dang, N. A. (2000). Changing gender relations in Vietnam's post Doi Moi era. Policy Research Report on Gender and Development, 14.

Maheswaran, D. (1994). Country of origin as a stereotype: effects of consumer expertise and attribute strength on product evaluations. Journal of Consumer Research, 21(2), 354-365. https://doi.org/10.1086/209403

McConnell, J. D. (1968). Effect of pricing on perception of product quality. Journal of Applied Psychology, 52, 331-314. https://doi.org/10.1037/h0026040 
The impacts of country of origin, price, and brand on consumer behavior toward cosmetics products

Mendoza, J., \& Baines, P. (2012). Towards a consumer price perception formation framework: A systematic review. Retrieved from http://anzmac.org/conference/2012/papers/173ANZMACFINAL.pdf

Millikan, L. E. (2001). Cosmetology, cosmetics, cosmeceuticals: definitions and regulations. Clinics in Dermatology, 19(4), 371-374. https://doi.org/10.1016/S0738-081X(01)00195-X

Monroe, K. B. (1976). The influence of price differences and brand familiarity on brand preference. Journal of Consumer Research, 3(6), 42-49. https://doi.org/10.1086/208649

Montgomery, C. A., \& Wernerfelt, B. (1992). Risk reduction and umbrella branding. Journal of Business, 65(1), 31-50. https://doi.org/10.1086/296556

Narayana, C. L. (1981). Aggregate images of American and Japanese products: implications on international marketing. Columbia Journal of World Business, 16(2), 31-35.

Nebenzahl, I. D., \& Jaffe, E. D. (1993). Estimating demand functions from the country-of origin effect. In N. G. Papadopoulos \& L. A. Heslop (Ed.), Product- country images: Impact and role in international marketing (pp. 159-78). New York, NY: International Business Press.

Nes, E., \& Bilkey, W. J. (1993). A multi-cue test of country-of-origin theory. In N. G. Papadopoulos \& L. A. Heslop (Ed.), Product-country image: Impact and role in international marketing (pp. 179-196). New York, NY: International Business Press.

Neumeier, M. (2006). The Brand Gap: How to bridge the distance between business strategy and design, Berkeley, CA: New Riders Publishing.

Nguyen, H. M., \& Sirikhoon, S. (2008). Cosmetic market in Vietnam. Västerås: Mälardalen University. School of Sustainable Development of Society and Technology.

Olander, F. (1969). The influence of price on the consumer's evaluation of products and purchases. In B. Taylor \& G. Wills (Eds.), Pricing strategy (pp. 50-69). Staples Press.

Ophuis, P. A. M. O., \& Trijp, H. C. M. V. (1995). Perceived quality: a market driven and consumer oriented approach. Food Quality and Preference, 6, 177-183. https://doi.org/10.1016/0950-3293(94)00028-T

Ozsomer, A., \& Cavusgil, S. T. (1991). Country-of-origin effects on product evaluations: A sequel to Bilkey and Nes Review. In M. C. Gilly et al. (Eds.), Proceedings of the American Marketing Association (pp. 269-77).

Papadopoulos, N., \& Heslop, L. A. (1993). Product-country image: Impact and role in international marketing. New York, NY: International Business Press.

Parasuraman, A., Grewal, D. \& Krishnan, R. (2004). Marketing research. Boston: Houghton Mifflin.

Parvin, N., \& Chowdhury, M. H. K. (2006). Consumer evaluations of beautifications: Effects of extrinsic cues. Asian Academy of Management Journal, 11(2), 89-104.

Perreault, W. D., \& Mcarthy, E. J. (1993). Basic marketing: A global-managerial approach. Irwin, IL: Homewood

Peterson, R. A., \& Jolibert, A. J. P. (1995). A meta-analysis of country of origin effects. Journal of International Business Studies, 26(4), 883-900. https://doi.org/10.1057/palgrave.jibs.8490824

Phau, I., \& Prendergast, G. (1999). Integrating country of origin research: concepts, methods and strategies. Journal of International Marketing and Exporting, 4(2), 71-83.

Piron, F. (2000). Consumers' perceptions of the country-of-origin effect on purchasing intentions of (in) conspicuous products. The Journal of Consumer Marketing, 17(4), 308-322. https://doi.org/10.1108/07363760010335330

Rajput, A. A., Kalhoro, S. H., \& Wasif, R. (2012). Impact of product price and quality on consumer buying behavior: Evidence from Pakistan. Interdisciplinary Journal of Contemporary Research in Business, 4(4), 485-496.

Rao, V. (1970). The salience of price in the perception and evaluation of product quality: A multi-dimensional measurement model and experimental test. Unpublished doctoral dissertation, University of Pennsylvania.

Richards, L. (2009). Consumer behavior implications for marketing strategies. eHow: Driven by Demand Media. Retrieved from http://www.ehow.com/info_8211169_implications-marketing-strategy.html

Rogers, T. M., Kaminski, P. F., Schoenbachler, D. D., \& Gordon,G. L. (1994). The effect of country-of-origin 
information on consumer purchase decision processes when price and quality information are available. Journal of International Consumer Marketing, 7(2), 73-109. https://doi.org/10.1300/J046v07n02_06

Rosa, D, I. (2004). Price knowledge: Effects of consumers' attitudes towards prices, demographics, and socio-cultural characteristics. The Journal of Product and Brand Management, 13(6), 406-428. https://doi.org/10.1108/10610420410560307

Roth, M. S., \& Romeo, J. B (1992).Matching product category and country image perceptions: A framework for managing country-of-origin effects. Journal of International Business Studies, 23(3), 477-497. https://doi.org/10.1057/palgrave.jibs.8490276

Samiee, S. (1994). Customer evaluation of products in a global market. Journal of International Business Studies, 25(3), 579-604. https://doi.org/10.1057/palgrave.jibs.8490213

Samiee, S., Shimp, T. A., \& Sharma, S. (2005). Brand origin recognition accuracy: its antecedents and consumers' cognitive limitations. Journal of International Business Studies, 36(4), 379-397. https://doi.org/10.1057/palgrave.jibs.8400145

Schaefer, A. (1997). Consumer knowledge and country-of-origin effects. European Journal of Marketing, 31(1), 56-72. https://doi.org/10.1108/03090569710157034

Schiffman, L. G., \& Kanuk, L. (2000). Consumer behavior. Upper Saddle River, NJ: Prentice Hall.

Schneider, G., Gohla, S., Schreiber, J., Kaden, W., Schonrock, U., Schmidt-Lewerkuhne, H., Kuschel, A., Petsitis, X., Pape, W., Ippen, H., \& Diembeck, W. (2001). Skin cosmetics. Ullmann's Encyclopedia of Industrial Chemistry. https://doi.org/10.1002/14356007.a24_219

Schooler, R. D. (1965). Product bias in the Central American common market. Journal of Marketing Research, 36(4), 394-397. https://doi.org/10.2307/3149486

Schweiger, G., Otter, T., \& Strebinger, A (1997). The influence of country of origin and brand on product evaluation and the implications thereof for location decisions. CEMS Business Review, 2, 5-26.

Shaver (2007). Brand attachment and brand attitude strength: Conceptual and empirical differentiation of two critical brand equity drivers. Journal of Marketing, 16-20.

Shenge, N. A. (2010). Impact of country-of-origin and price on product's advertisement efficacy", Journal of Social Science, 24(3), 193-201.

Shrimp, T. A. (2007). Advertising, promotion, and other aspects of integrated marketing communications (7th ed.).Mason: South Western Cengage Learning.

Solomon, M. R. (1999). Consumer behavior ( $3^{\text {rd }}$ ed). Upper Saddle River, New Jersey: Prentice Hall.

Stafford, J. E., \& Enis, B. M. (1969). The price-quality relationship: An extension. Journal of Marketing Research, 6, 456-458. https://doi.org/10.2307/3150082

Stephan, Z. (2008). Exploring asymmetric effects in the formation of retail price satisfaction. Journal of Retailing \& Consumer Services, 15(5), 335-347. https://doi.org/10.1016/j.jretconser.2007.08.005

Stephan, Z. (2011). Integrating emotions in the analysis of retail price images. Psychology \& Marketing, 28(4). 330-359. https://doi.org/10.1002/mar.20355

Suman, S., \& Mansi, K. (2014). Impact of branding strategies on consumer buying behavior in FMCD industry. IOSR Journal of Business and Management, 16(1), 126-135. https://doi.org/10.9790/487X-1614126135

Swaha, B., \& Sritama, M. (2012). Consumer behavior and impact of brand - A Study on South Zone of Kolkata city. Voice of Research, 1(2).

Swan, J. (1974). Price-product performance competition between retailer and manufacturer brands. Journal of Marketing, 38(3), 52-59. https://doi.org/10.2307/1249850

Tang, C. S., Bell, D. R., \& Ho, T. (2001). Store choice and shopping behaviour: How price format works. California management review, 43(2), 56. https://doi.org/10.2307/41166075

Thakor, M. V., \& Lavack, A. M. (2003). Effects of perceived brand origin associations on consumer perception of quality. Journal of Product and Brand Management, 12(6), 394-407. https://doi.org/10.1108/10610420310498821

Thakor, M. V., \& Pachetu, B. G. (1997). Foreign branding and its effects on product perceptions and attitudes: a replication and extension in a multicultural setting. Journal of Marketing Theory and Practice, 5(1), 15-30. https://doi.org/10.1080/10696679.1997.11501747 
The impacts of country of origin, price, and brand on consumer behavior toward cosmetics products

Thorelli, H. B., Lim, J. S., \& Jongsuk, Y. (1989). Relative importance of country of origin warranty and retail store image on product evaluations. International Marketing Review, 6(1), 35-46. https://doi.org/10.1108/EUM0000000001501

Tse, D. K., \& Gorn, G. J. (1993). An experiment on the salience of country of origin in the area of global brands. Journal of International Marketing, 1(1), 57-76.

Tse, D. K., \& Lee, W. (1993). Removing negative country images: effects of decomposition, branding and product experience. Journal of International Marketing, 1(4), 25-48.

Tull, D. S., Boring. R. S., \& Gonsior, M. H. (1964). A note on the relationship of price and imputed quality. Journal of Business, 37, 186-191. https://doi.org/10.1086/294682

Ulgado, F. M., \& Lee, M. (1998). The Korean versus American marketplace: Consumer reactions to foreign products. Psychology and Marketing, 15(6), 595-614. https://doi.org/10.1002/(SICI)1520-6793(199809)15:6<595::AID-MAR7>3.0.CO;2-1

Usunier, J. C. (2006). Relevance in business research: The case of country-of-origin research in marketing. European Management Review, 3(1), 60-73. https://doi.org/10.1057/palgrave.emr.1500049

Veale, R. \& Quester, P. (2009). Do consumer expectations match experience? Predicting the influence of price and country of origin on perceptions of product quality. International Business Review, 18(2), 134-144. https://doi.org/10.1016/j.ibusrev.2009.01.004

Verlegh, P. W. J., Steenkamp, J. B. E. M., \& Meulenberg, M. T. G. (2005). Country-of-origin effects in consumer processing of advertising claims. International Journal of Research in Marketing, 22(2), 127-139. https://doi.org/10.1016/j.ijresmar.2004.05.003

Vuong, Q. H. (2012). Vietnam's economic challenges. The Hub: International perspectives. Retrieved from http://www.stratfor.com/the-hub/vietnams-economic-challenges

Wall, M., Liefeld, J., \& Heslop, L. A. (1991). Impact of country-or-origin cues on consumer judgments in multi-cue situations. Journal of the Academy of Marketing Science, 19(2), 105-113. https://doi.org/10.1007/BF02726002

Wheatley, J. J., \& Chiu, J. S. Y. (1977).The effects of price, store image, and product and respondent characteristics on perception of quality. Journal of Marketing Research, 14(2), 181-186. https://doi.org/10.2307/3150467

White, P. D., \& Cundiff, E. W. (1978). Assessing the quality of industrial products. Journal of Marketing, 80-86. https://doi.org/10.2307/1250332

Xiaoling, H., Leeva, L., Charlene, X., \& Jun, Z. (2008). The effects of country-of-origin on Chinese consumers' wine purchasing behavior. Journal of Technology Management in China, 3(3), 292-306. https://doi.org/10.1108/17468770810916195

Yaprak, A. (1978). Formulating a multinational marketing strategy: A deductive, cross-national consumer behavior model. Georgia State University, Atlanta, GA, Doctoral dissertation.

Yeomans, M. (2012). Global beauty market to reach \$265 billion in 2017 due to an increase in GDP. Breaking News on Cosmetics Formulation \& Packaging in North America. Retrieved from http://www.cosmeticsdesign.com/Market-Trends/Global-beauty-market-to-reach-265-billion-in-2017-d ue-to-an-increase-in-GDP

Zafar, U. A., Johnson, J. P., Yang, X., Fatt, C. K., Teng, H. S., \& Boon, L. C. (2004). Does country of origin matter for low-involvement products. International Marketing Review, 21(1), 102-120. https://doi.org/10.1108/02651330410522925

Zeithaml, A. V. (1988). Consumer perceptions of price, quality, and value: A means-end model and synthesis of evidence. Journal of Marketing, 52, 2-22. https://doi.org/10.2307/1251446

Zhang, Y. (1996). Chinese consumers evaluation of foreign product: the influence of culture, product types and product presentation format. European Journal of Marketing, 30(12), 50-68. https://doi.org/10.1108/03090569610153309 
Luong, D. B., Vo, T. H. G., \& Le, K. N. 